\title{
Penerapan Model Pembelajaran Kooperatif Tipe Student Facilitator and Explaining (SFAE) untuk Meningkatkan Kemampuan Pemecahan Masalah Matematis Siswa
}

\author{
Tahir \\ Universitas Sembilanbelas November Kolaka \\ tahir.anwar.ta89@gmail.com
}

\begin{abstract}
ABSTRAK
Penelitian ini merupakan penelitian tindakan kelas dengan menerapkan model pembelajaran Kooperatif tipe $S F A E$ untuk meningkatkan kemampuan pemecahan masalah matematis siswa yang dilakukan sebanyak dua siklus dimana setiap siklusnya dilakukan dua kali pertemuan. Hasil penelitian menunjukkan rata-rata hasil kemampuan pemecahan masalah siswa pada siklus I yaitu 69,32 dengan persentase ketuntasan siswa yang mendapat nilai $\geq 70$ adalah $64 \%$. Sehingga hasil siklus I belum mencapai indikator yang diharapkan yaitu $80 \%$ ketuntasan siswa maka dilanjutkan ke siklus II. Hasil pada siklus II diperoleh rata-rata kemampuan pemecahan masalah matematis siswa 78,54 dengan persentase ketuntasan siswa yang mendapat nilai $\geq 70$ adalah $88 \%$ yang berarti bahwa hasil belajar siswa pada siklus II ini telah mencapai indikator kerja yang ditetapkan peneliti, dilihat dari keaktivan belajar siswa pada siklus I adalah $74 \%$ dan pada siklus II mengalami peningkatan yaitu $87,5 \%$ dimana hasil tersebut telah mencapai indikator kerja yang peneliti tetapkan. Dengan membandingkan hasil siklus II dengan hasil yang diperoleh pada siklus I dapat disimpulkan dengan penerapan model pembelajaran kooperatif tipe $S F A E$ dapat meningkatkan kemampuan pemecahan masalah matematis siswa.
\end{abstract}

Kata kunci: pembelajaran kooperatif tipe SFAE, PTK, kemampuan pemecahan masalah.

\begin{abstract}
The purpose of this study is the application of the SFAE type Cooperative learning model to improve students' mathematical problem solving abilities. This research is a classroom action research conducted in two cycles where each cycle is done twice. The results showed the average student learning outcomes in the first cycle was 69.32 with the percentage of completeness of students who scored $\geq 70$ is $64 \%$. So that the results of the first cycle have not yet reached the expected indicator of $80 \%$ student completeness then proceed to the second cycle. The results of the second cycle obtained an average mathematical problem solving ability of students 78.54 with the percentage of completeness of students who scored $\geq 70$ is $88 \%$, which means that student learning outcomes in the second cycle have reached the work indicators set by researchers. That can be seen with the activity of student learning in the first cycle is $74 \%$ and in the second cycle has increased by $87.5 \%$ where the results have reached the work indicators that researchers set. From the results of the second cycle, it can be concluded that the application of the SFAE type of cooperative learning model can improve students' mathematical problem solving abilities. .
\end{abstract}

Keywords: cooperative learning type SFAE, classroom action research, problem solving ability. 


\section{PENDAHULUAN}

Matematika merupakan ilmu dasar yang memiliki peran penting dalam kehidupan manusia, terutama dalam meningkatkan kualitas pendidikan manusia. Matematika dapat meningkatkan pola pikir manusia dan berperan dalam setiap kehidupan. Matematika merupakan sarana untuk menanamkan kebiasaan bernalar dalam pikiran seseorang, karena matematika merupakan ilmu terapan dalam kehidupan sehari-hari. Matematika sebagai salah satu sarana berpikir ilmiah yang sangat diperlukan untuk menumbuhkan kemampuan berberpikir ilmiah yang sangat diperlukan untuk menumbuhkan kemampuan berpikir, sistematis dan kritis dari peserta didik untuk menunjang keberhasilan belajarnya dalam menempuh pendidikan yang lebih tinggi (Sofyan, 2013).

Keberhasilan pembelajaran dipengaruhi oleh proses pembelajaran dan pelaksanaan yang baik pula. Di dalam pembelajaran terdapat interaksi antara guru dan siswa, sedangkan mengajar merupakan kegiatan yang dilakukan oleh guru. kegiatan mengajar yang dilakukan oleh guru sangat mempengaruhi kegiatan belajar siswa. Agar pelaksanaan pengajaran berjalan efesien maka diperlukan perencanaan yang tersusun secara sistematis dalam proses belajar mengajar yang lebih bermakna dan mengaktifkan siswa (Mustofa, 2015). Pelaksanaan proses pembelajaran perlu dilakukan secara sistematis berdasarkan prosedur pembelajaran yang telah dikembangkan. Oleh karena itu, salah satu kemampuan yang harus dimiliki oleh guru adalah mampu memahami dan melaksanakan prosedur pembelajaran dalam kelompok maupun secara individu. Salah satu aspek yang mempengaruhi keberhasilan pembelajaran adalah kemampuan guru dalam mengelola pembelajaran, dalam prosesnya pengelolaan tersebut harus diarahkan hingga menjadi suatu proses yang bermakana dalam pembentukan kemampuan siswa.

Namun, pada kenyataannya pembelajaran Matematika di sekolah saat ini masih belum sesuai dengan harapan. Seperti yang diperoleh dari hasil observasi dan wawancara dengan salah satu guru matematika di SMP Negeri 2 Ladongi didapat bahwa ketuntasan hasil belajar siswa hanya mencapai $28 \%$ atau 7 dari 25 siswa yang tuntas. Lebih lanjut dari hasil analisis ulangan harian siswa juga diketahui kemampuan siswa dalam mengerjakan soal-soal cerita yang melatih kemampuan siswa dalam memecahkan masalah masih tergolong rendah. Hal ini disebabkan siswa hanya terbiasa mengerjakan soal sesuai contoh yang diberikan dan siswa kurang berlatih dalam menyelesaikan soal-soal non rutin. Sedangkan kemampuan pemecahan masalah sangat dibutuhkan di dalam pelajaran matematika, karena pemecahan masalah merupakan suatu aktivitas intelektual untuk mencari penyelesaian masalah yang dihadapi dengan menggunakan bekal pengetahuan yang sudah dimiliki (Slameto, 2010).

Salah satu solusi yang dapat digunakan untuk mengatasi masalah di atas adalah dengan penggunaan model pembelajaran Kooperatif tipe Student FacilitatorAnd Explaining (SFAE). Menurut Huda, model pembelajaran Kooperatif tipe Student FacilitatorAnd Explaining (SFAE) merupakan penyajian materi ajar yang diawali dengan penjelasan secara terbuka, kemudian memberi kesempatan kepada siswa untuk menjelaskan kembali kepada temantemannya dan diakhiri dengan penyampaian semua materi kepada semua siswa. Dengan Tujuan untuk membanngkitkan keberanian siswa untuk mengemukakan pendapatnya dan mengajarkan siswa untuk berbagi pengetahuan. Sehingga siswa sendiri dapat merasakan manfaat dari belajar dengan model pembelajaran ini yaitu, memotivasi siswa untuk menjadi yang terbaik dalam menjelaskan materi dan melatih siswa untuk berperan menjadi guru 
dengan demikian proses belajar mengajar menjadi menyenangkan (Oemar, 2011). Selain alasan tersebut, penelitian yang dilakukan Yufitri (2018) menyimpulkan Berdasarkan hasil penelitian dan pembahasan dapat disimpulkan bahwa hasil belajar matematika siswa kelas VIII SMP Negeri B. Srikaton setelah penerapan model pembelajaran kooperatif tipe student facilitator and explaining secara signifikan tuntas. Sehingga melalui penerapan model pembelajaran Kooperatif tipe $S F A E$ diharapkan dapat meingkatkan kemampuan pemecahan masalah matematis siswa kelas VIII SMP Negeri 2 Ladongi.

\section{METODE}

Jenis penelitian ini adalah penelitian tindakan kelas dimana yang menjadi subjek penelitian adalah siswa kelas VIIIA SMP Negeri 2 Ladongi pada semster genap tahun pelajaran $2018 / 2019$.

\subsection{Desain Penelitian}

Prosedur penelitian ini terdiri dari beberapa siklus. Tiap siklus dilaksanakan sesuai dengan indikator yang ingin dicapai. Dengan desain sebagai berikut.

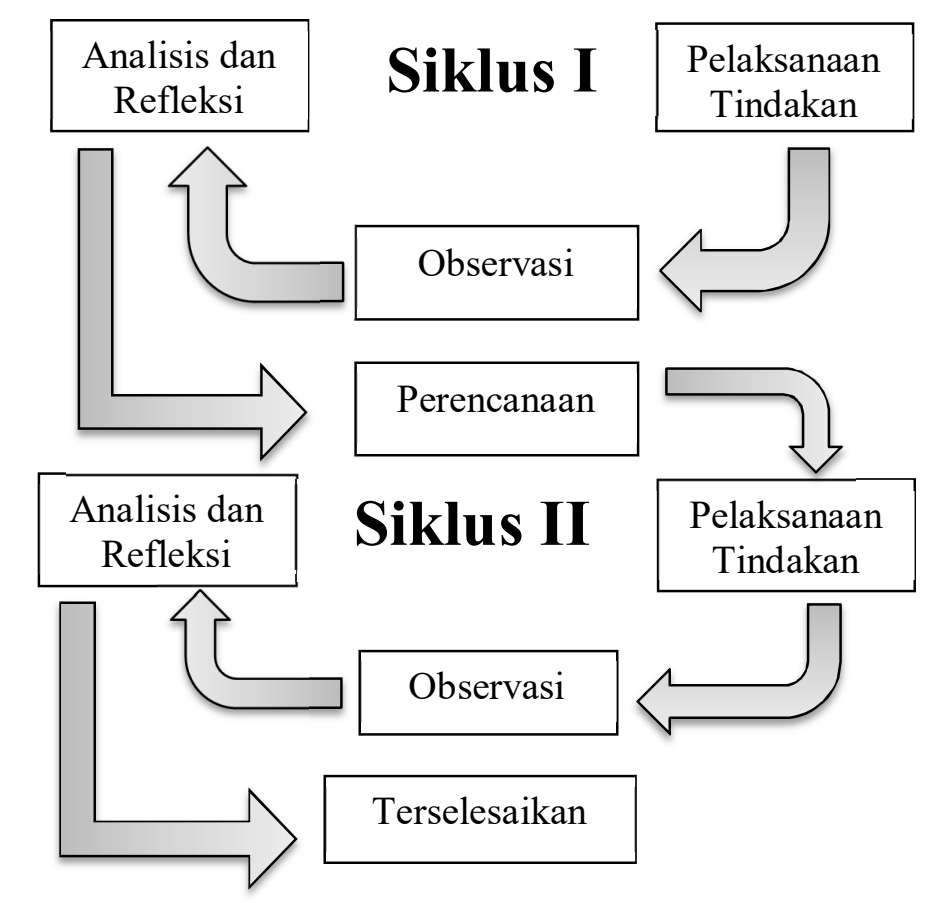

Gambar 1. Skema siklus penelitian tindakan kelas (PTK) (Kusnandar, 2008)

\subsection{Metode Pengumpulan Data}

Tes

Tes diberikan kepada siswa pada awal pertemuan sdebelum pembelajaran dan pada setiap akhir siklus. Digunakan untuk mengetahui kemampuan pemecahan masalah matematika siswa. Instrumen yang digunakan berupa Soal tes dimana soal yang digunakan adalah soal-soal matematika yang sebelumnya telah diuji valid dan reliabel serta diperhatikan tingkat kesukaran dan daya pembedanya. 


\section{Observasi}

Observasi digunakan untuk memperoleh informasi terkait dengan aktivitas siswa selama proses pembelajaran berlangsung dan aktivitas guru dalam mengelola kelas. Instrumen yang digunakan berupa lembar observasi. lembar observasi digunakan untuk mengetahui bagaimana aktivitas siswa selama pembelajaran berlangsung dan aktivitas guru dalam mengelola kelas baik pada kelas eksperimen maupun kelas kontrol.

\subsection{Metode Analisis Data}

Data yang telah diperoleh dari hasil observasi dianalisis secara kuantitatif dan kualitatif. Analisis kualitatif digunakan untuk menjelaskan hasil-hasil tindakan yang mengarah keaktifan siswa dan guru selama proses pembelajaran berlangsung. Sedangkan analisis kuantitatif digunakan untuk mengelolah data yang diperoleh dari tes kemampuan pemecahan masalah.

1. Menentukan rata-rata nilai hasil tes dengan menggunakan rumus

$$
\overline{\mathrm{X}}=\frac{\sum_{i=1}^{n} \mathrm{X}_{i}}{n}
$$

(Kadir, 2015)

dengan

$\overline{\mathrm{X}}$ : mean (rata-rata),

$\mathrm{X}_{i}$ : nilai tiap data,

$n$ : banyak siswa (Kadir, 2015).

2. Menentukan tingkat pencapaian ketuntasan belajar siswa dengan menggunakan rumus

$\%$ Tuntas $=\frac{\sum_{i=1}^{n} f_{i}}{n} \times 100 \%$

(Zainal, 2012)

3. Menentukan Aktivitas Belajar siswa dan Aktivitas Mengajar Guru

Aktivitas selama proses pembelajaran dianalisis secara kualitatif berdasarkan aspek yang telah ditentukan dalam lembar observasi. Rumus menghitung persentase hasil observasi yaitu

persentase $=\frac{\sum S P}{\sum S M} X 100 \% \quad$ (Sofhian, 2015)

dengan:

SP : skor perolehan,

SM : skor maksimal.

Tabel 1. Kualifikasi Penilaian Aktivitas Guru dan Aktivitas Siswa

\begin{tabular}{ccc}
\hline No. & Persentase (\%) & Kualifikasi \\
\hline 1 & $86-100$ & SangatBaik \\
2 & $76-85$ & Baik \\
3 & $66-75$ & Cukup Baik \\
4 & $56-65$ & Kurang Baik \\
5 & $\leq 55$ & Tidak Baik \\
\hline \multicolumn{3}{c}{ Sumber: Depdiknas (Andari, 2013) }
\end{tabular}




\subsection{Kriteria Keberhasilan}

Indikator keberhasilan dalam Penelitian Tindakan Kelas ini adalah sebagai berikut:

a. Dari segi proses, proses pelaksanaan model pembelajaran kooperatif tipe SFAE yang dilakukan oleh guru dan siswa minimal $80 \%$ aspek yang diobservasi dapat terlaksanakan.

b. Dari segi hasil belajar siswa dikatakan tuntas secara klasikal jika 80\% siswa telah memperoleh nilai minimal 70, yang merupakan Kriteria Ketuntasan Minimal (KKM) yang telah ditentukan oleh pihak sekolah.

\section{HASIL DAN PEMBAHASAN}

Penelitian ini dilaksanakan dalam dua siklus dimana setiap siklusnya dilakukan dua kali pertemuan dengan menerapkan model pembelajaran kooperatif tipe SFAE. Namun sebelum pelaksaan siklus terlebih dahulu dilakukan tes awal untuk memperoleh gambaran nyata dari kemapuan pemecahan masalah matematis siswa.

\subsection{Hasil Kemampuan Pemecahan Masalah Matematis Siswa}

Nilai kemampuan pemecahan masalah matematis siswa diperoleh setelah seluruh siswa kelas VIIIA SMP Negeri 2 menjawab soal-soal yang diberikan dan bentuk soal yang diberikan adalah soal essay dan diberikan pada awal pertemuan untuk memperoleh data awal dan pada akhir setiap siklus. Ringkasan nilai tersebut dapat dilihat pada tabel berikut.

\begin{tabular}{clccc} 
Tabel 2. Hasil Kemampuan Pemecahan Masalah Matematis Sisw \\
\hline \multirow{2}{*}{ No. } & \multicolumn{2}{c}{ Pencapaian } & \multicolumn{3}{c}{ Siklus } \\
\cline { 3 - 5 } & & Tes Awal & I & II \\
\hline 1 & Jumlah Siswa & 70 & 70 & 70 \\
2 & KKM & 6 & 16 & 22 \\
3 & Jumlah Siswa Tuntas & $24 \%$ & $64 \%$ & $88 \%$ \\
4 & Persentase Ketuntasan & 73,6 & 87,08 & 90,04 \\
5 & Nilai Terbesar & 23,14 & 51,53 & 68,71 \\
6 & Nilai Terkecil & 42,67 & 69,32 & 78,54 \\
7 & Rata-rata & & & \\
\hline
\end{tabular}

\subsection{Analisis Lembar Observasi Guru}

Lembar observasi guru digunakan untuk melihat, apakah guru dapat melaksanakan proses pembelajaran sesuai dengan sintaks yang ada dalam model pembelajaran kooperatif tipe SFAE. Hasil lembar observasi tersebut disajikan pada Gambar 2.

\subsection{Analisis Lembar Observasi Aktivitas Siswa}

Lembar penilaian aktivitas siswa digunakan untuk melihat keaktivan siswa selama proses pembelajaran berlangsung. Hasil lembar observasi tersebut disajikan pada Gambar 3. 


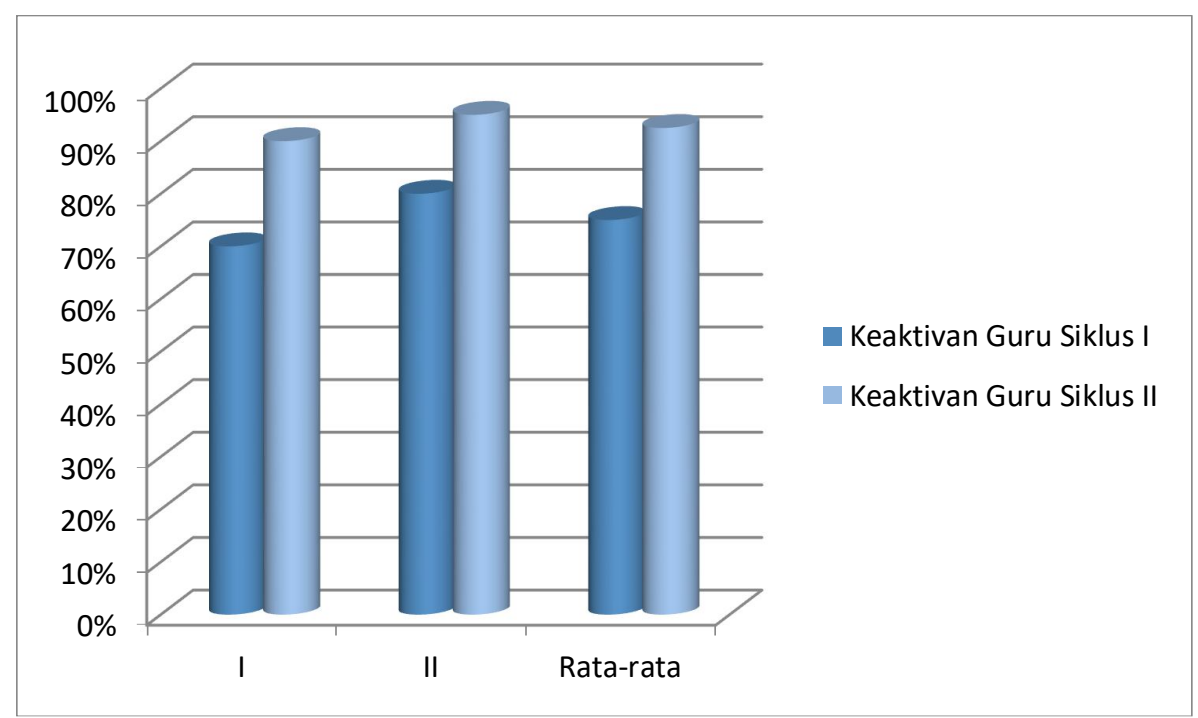

Gambar 2. Hasil Analisi Lembar Observasi Guru

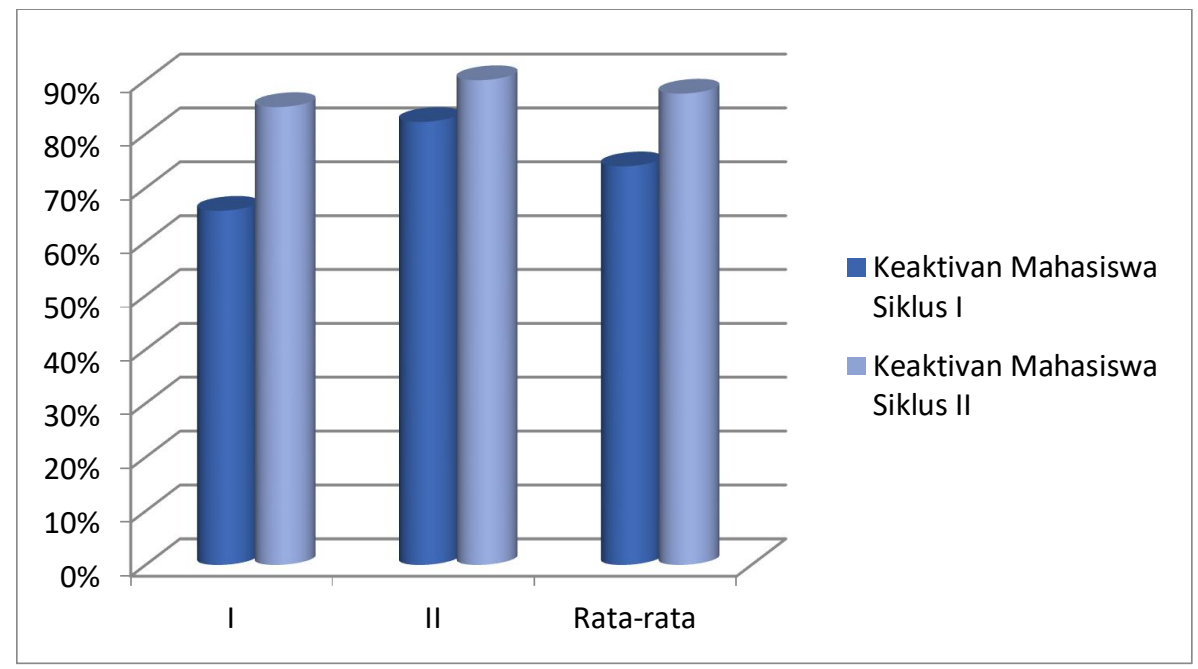

Gambar 3. Hasil Analisi Lembar Observasi Siswa

\subsection{Pembahasan}

Kelas yang digunakan sebagi subjek penelitian adalah kelas VIIIA dimana di kelas ini diterapkan model pembelajaran kooperatif tipe SFAE. model pembelajaran kooperatif tipe student facilitator and explaining adalah model pembelajaran yang memberikan kesempatan kepada siswa untuk menjelaskan kepada peserta didik lainnya baik melalui bagan/peta konsep maupun yang lainnya setelah guru menyampaikan materi pembelajaran. Dalam pelaksanaan penelitian ini, peneliti melakukan dua siklus yaitu setiap siklus dilakukan dua kali pertemuan dan satu kali tes. Tes dilakukan untuk mengetahui peningkatan kemampuan pemecahan masalah matematis siswa setelah penerapan model pembelajaran disetiap siklus.

\section{Siklus I}

Siklus I dilaksanakan sesuai dengan prosedur penelitian yang telah direncanakan, dengan mengikuti langkah-langkah model pembelajaran kooperatif tipe SFAE. Siklus ini dilaksanakan 
dua kali pertemuan dan satu kali tes siklus. Dari hasil tes siklus I diperoleh nilai rata-rata siswa siklus I mencapai 69,32 dan ketuntasan belajar secara klasikal sebesar 64\%. Hasil tersebut jika dilihat nilai rata-rata kelas berada di bawah KKM (70) dan ketuntasan secara klasikal persentase belum mencapai tolak ukur keberhasilan yang ditetapkan peneliti yaitu $80 \%$. Selain dari segi nilai, dari segi aktivitas belajar siswa juga belum mencapai indikator kinerja yang ditetapkan yaitu $80 \%$ yang mana rata-rata keaktivan siswa pada siklus I ini hanya $74 \%$ atau berada kategori cukup baik. Tetapi, hasil kemampuan pemecahan masalah matematis siswa tersebut mengalami peningkatan bila dibandingkan dengan nilai awal. Hal ini dapat dilihat dari rata-rata nilai awal hanya 42,67 dengan ketuntasan 24\%, nilai terendah maupun tertinggi juga mengalami peningkatan. Karena hasil yang diperoleh belum mencapai tolak ukur keberhasilan yang ditetapkan peneliti, sehingga penelitian dilanjutkan ke siklus II dengan mengevaluasi kekurangan-kekurangan yang terjadi selama pelaksanaan siklus I dengan memperhatikan lembar observasi siswa, lembar observasi guru dan masukan dari observer.

Setelah melihat data baik dari pengamatan observasi dan hasil kolaborasi dengan observer untuk kemudian dianalisis maka siklus pertama secara umum sudah berjalan baik. Namun masih ditemukan beberapa kekurangan, kekurangan tersebut seperti siswa tidak duduk tenang dan rapi, tidak tepat dalam menemukan jawaban, tidak mempresentasikan jawaban dengan benar dan mudah dipahami, serta masih banyak siswa yang tidak menanggapi hasil presentase kelompok lain. Hal ini disebabkan karena siswa masih belum terbiasa dengan perubahan model pembelajaran dan pergantian guru, sehingga siswa masih kaku di dalam pembelajaran. Selain kekurangan dari siswa, dalam pembelajaran, guru juga masih memiliki beberapa kekurangan, seperti tidak membimbing siswa yang melakukan kesalahan dan tidak memotivasi siswa untuk memperbaiki kesalahannya, tidak mendorong siswa untuk menanyakan suatu masalah yang berkaitan dengan materi yang dibahas, serta masih sering tidak memberikan penilaian terhadap hasil persentasi.

Setelah mengetahui kekurang-kekurangan yang terjadi dalam pembelajaran pada siklus I, selanjutnya peneliti dan guru mitra mencari solusi untuk mengatasi kekurangan pada siklus I agar tidak terjadi lagi pada siklus ke II. Sehingga diperoleh kesimpulan bahwa masih perlu ditingkatkan lagi terutama guru dalam meningkatkan motivasi belajar siswa, memberi penguatan kepada siswa yang bertanya dan yang mau mengerjakan soal di papan tulis, agar dapat memotivasi siswa yang lain untuk turut aktif dalam pembelajaran. Selanjutnya juga adanya persiapan dan perencanaan yang matang mengenai kegiatan, alat, bahan ajar atau media pembelajaran yang diperlukan dalam proses pembelajaran. Guru perlu membimbing siswa dalam menjawab soal-saol latihan, serta guru perlu perlu memperhatikan pengelolaan waktu pembelajaran agar sesuai alokasi waktu yang telah direncanakan.

\section{Siklus II}

Seperti siklus I, pada siklus II pembelajaran juga dilaksanakan dua kali pertemuan dan satu kali tes siklus. Hasil refleksi pada siklus I selanjutnya dimaksimalkan pada siklus II untuk memperoleh hasil yang maksimal. Pada siklus II siswa telah terbiasa model pembelajaran kooperatif tipe $S F A E$. Hal ini terlihat dari semakin banyak siswa yang lebih berperan aktif dalam proses pembelajaran dan pembelajaran semakin menyenangkan.

Setelah siklus II, perolehan nilai siswa meningkat dengan nilai rata-rata adalah 78,54 dengan ketuntasan belajar $88 \%$ atau 22 dari 25 orang siswa yang tuntas. Dimana pada siklus II 
hasil yang diperoleh siswa telah mencapai indikator kerja yang ditetapkan peneliti, yaitu ketuntasan belajar siswa di atas $80 \%$. Berdasarkan dari aktivitas belajar siswa juga telah mencapai indikator keaktifan siswa yang ditetapkan oleh peneliti yaitu 87,5\%.

\section{SIMPULAN}

Berdasarkan hasil penelitian tindakan kelas ini, maka dapat disimpulkan bahwa dengan penerapan model pembelajaran kooperatif tipe $S F A E$ dapat meningkatkan kemampuan pemecahan masalah matematis siswa kelas VIIIA SMP Negeri 2 Ladongi. Hal ini dapat dilihat dari rata-rata hasil belajar siswa pada siklus I yaitu 69,32 dengan persentase ketuntasan siswa yang mendapat nilai $\geq 70$ adalah $64 \%$. Sehingga hasil siklus I belum mencapai indikator yang diharapkan yaitu $80 \%$ ketuntasan siswa maka dilanjutkan ke siklus II. Hasil pada siklus II diperoleh rata-rata kemampuan pemecahan masalah matematis siswa 78,54 dengan persentase ketuntasan siswa yang mendapat nilai $\geq 70$ adalah $88 \%$ yang berarti bahwa hasil belajar siswa pada siklus II ini telah mencapai indikator kerja yang ditetapkan peneliti. Itu dapat dilihat dengan keaktivan belajar siswa pada siklus I adalah 74\% dan pada siklus II mengalami peningkatan yaitu $87,5 \%$ dimana hasil tersebut telah mencapai indikator kerja yang peneliti tetapkan.

\section{DAFTAR PUSTAKA}

Andari, D. (2013). Penerapan model pembelajaran student facilitator and explaining (SFAE) untuk meningkatkan hasil belajar fisika SMP Nurul Islam. http://lib.unnes.ac.id/17899/1/4201408061.pdf. diakses 21 Januari 2019.

Amri, Sofian. (2013). Pengembangan dan Model Pembelajaran dalam kurikulum 2013. Prestasi Pustaka, Jakarta.

Arifin, Zainal. (2012). Evaluasi pembelajaran Bandung. Bandung: PT Remaja Rosdakarya.

Hamalik, Oemar. (2011). Proses Belajar Mengajar. Jakarta: Bumi Aksara.

Kadir. (2015). Statistika Terapan. Depok: Rajawali Pers.

Kunandar. (2008). Langkah Mudah Penelitian Tindakan Kelas (PTK) sebagai Perkembangan Profesi Guru. Jakarta: PT Raja Grafindo Persada.

Siregar. Shofian, (2015). Metode Penelitian Kuantitatif:Dilengkapi Perbandingan Perhitungan Manual \& SPSS, Edisi Pertama. Jakarta: Kencana.

Slameto. (2010) Belajar dan Faktor- Faktor yang Mempengaruhi. Jakarta: Rineka Cipta.

Thobroni, M. Arif Mustofa. (2015). Belajar dan pembelajaran. Ar-Ruzz. Media, Yogyakarta.

Yanto, Yufitri. (2018). penerapan Model Pembelajaran Student Facilitator and Explaining Terhadap Hasil Belajar Matematika Siswa. Jurnal pendidikan matematika, 1(1). 53-60. 